\title{
Hygroscopicity of nanoparticles produced from homogeneous nucleation in the CLOUD experiments
}

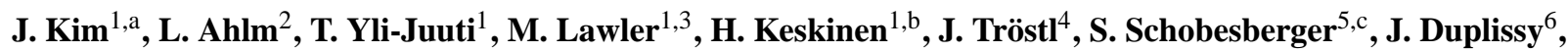

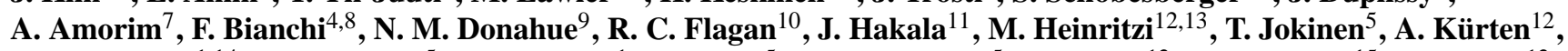
A. Laaksonen ${ }^{1,14}$, K. Lehtipalo ${ }^{5}$, P. Miettinen ${ }^{1}$, T. Petäjä ${ }^{5}$, M. P. Rissanen ${ }^{5}$, L. Rondo ${ }^{12}$, K. Sengupta ${ }^{15}$, M. Simon ${ }^{12}$, A. Tomé ${ }^{7,16}$, C. Williamson ${ }^{12}$, D. Wimmer ${ }^{5,8}$, P. M. Winkler ${ }^{17}$, S. Ehrhart ${ }^{12,18}$, P. Ye ${ }^{9}$, J. Kirkby ${ }^{12,18}$, J. Curtius ${ }^{12}$, U. Baltensperger ${ }^{4}$, M. Kulmala ${ }^{5}$, K. E. J. Lehtinen ${ }^{1,19}$, J. N. Smith ${ }^{1,3}$, I. Riipinen ${ }^{2}$, and A. Virtanen ${ }^{1}$

${ }^{1}$ Department of Applied Physics, University of Eastern Finland, Kuopio, Finland

${ }^{2}$ Department of Applied Environmental Science, Stockholm University, Stockholm, Sweden

${ }^{3}$ National Centre for Atmospheric Research, Boulder, CO 80305, USA

${ }^{4}$ Laboratory of Atmospheric Chemistry, Paul Scherrer Institute, Villigen, Switzerland

${ }^{5}$ Department of Physics, P.O. Box 64, 00014 University of Helsinki, Helsinki, Finland

${ }^{6}$ Helsinki Institute of Physics, P.O. Box 64, 00014 University of Helsinki, Helsinki, Finland

${ }^{7}$ CENTRA-SIM, University of Lisbon, Lisbon, Portugal

${ }^{8}$ Institute for Atmospheric and Climate Science, ETH Zurich, 8092 Zurich, Switzerland

${ }^{9}$ Carnegie Mellon University, Center for Atmospheric Particle Studies, 5000 Forbes Avenue, Pittsburgh, PA 15213, USA

${ }^{10}$ California Institute of Technology, 210-41, Pasadena, CA 91125, USA

${ }^{11}$ Division of Atmospheric Sciences, P.O. Box 64, 00014 University of Helsinki, Helsinki, Finland

${ }^{12}$ Goethe University of Frankfurt, Institute for Atmospheric and Environmental Sciences, Altenhöferallee 1, 60438 Frankfurt am Main, Germany

${ }^{13}$ University of Innsbruck, Institute for Ion and Applied Physics, 6020 Innsbruck, Austria

${ }^{14}$ Finnish Meteorological Institute, PL 501, 00101 Helsinki, Finland

${ }^{15}$ University of Leeds, School of Earth and Environment, Leeds LS2 9JT, UK

${ }^{16}$ University of Beira Interior, Beira, Portugal

${ }^{17}$ Faculty of Physics, University of Vienna, Boltzmanngasse 5, 1090 Vienna, Austria

${ }^{18}$ CERN, 1211 Geneva, Switzerland

${ }^{19}$ Finnish Meteorological Institute, Kuopio Unit, Kuopio, Finland

${ }^{a}$ now at: Arctic research center, Korea Polar Research Institute, Incheon, South Korea

bnow at: Department of Physics, P.O. Box 64, 00014 University of Helsinki, Helsinki, Finland

${ }^{c}$ now at: Department of Atmospheric Sciences, University of Washington, Seattle, WA 98195, USA

Correspondence to: A. Virtanen (annele.virtanen@uef.fi)

Received: 8 June 2015 - Published in Atmos. Chem. Phys. Discuss.: 20 July 2015

Revised: 11 November 2015 - Accepted: 17 December 2015 - Published: 18 January 2016

Abstract. Sulfuric acid, amines and oxidized organics have
been found to be important compounds in the nucleation
and initial growth of atmospheric particles. Because of the
challenges involved in determining the chemical composi-
tion of objects with very small mass, however, the properties
of the freshly nucleated particles and the detailed pathways
of their formation processes are still not clear. In this study, we focus on a challenging size range, i.e., particles that have grown to diameters of 10 and $15 \mathrm{~nm}$ following nucleation, and measure their water uptake. Water uptake is useful information for indirectly obtaining chemical composition of aerosol particles. We use a nanometer-hygroscopicity tandem differential mobility analyzer (nano-HTDMA) at subsaturated conditions (ca. $90 \%$ relative humidity at $293 \mathrm{~K}$ ) to 
measure the hygroscopicity of particles during the seventh Cosmics Leaving OUtdoor Droplets (CLOUD7) campaign performed at CERN in 2012. In CLOUD7, the hygroscopicity of nucleated nanoparticles was measured in the presence of sulfuric acid, sulfuric acid-dimethylamine, and sulfuric acid-organics derived from $\alpha$-pinene oxidation. The hygroscopicity parameter $\kappa$ decreased with increasing particle size, indicating decreasing acidity of particles. No clear effect of the sulfuric acid concentration on the hygroscopicity of $10 \mathrm{~nm}$ particles produced from sulfuric acid and dimethylamine was observed, whereas the hygroscopicity of $15 \mathrm{~nm}$ particles sharply decreased with decreasing sulfuric acid concentrations. In particular, when the concentration of sulfuric acid was $5.1 \times 10^{6}$ molecules $\mathrm{cm}^{-3}$ in the gas phase, and the dimethylamine mixing ratio was $11.8 \mathrm{ppt}$, the measured $\kappa$ of $15 \mathrm{~nm}$ particles was $0.31 \pm 0.01$ : close to the value reported for dimethylaminium sulfate (DMAS) $\left(\kappa_{\mathrm{DMAS}} \sim 0.28\right)$. Furthermore, the difference in $\kappa$ between sulfuric acid and sulfuric acid-dimethylamine experiments increased with increasing particle size. The $\kappa$ values of particles in the presence of sulfuric acid and organics were much smaller than those of particles in the presence of sulfuric acid and dimethylamine. This suggests that the organics produced from $\alpha$ pinene ozonolysis play a significant role in particle growth even at $10 \mathrm{~nm}$ sizes.

\section{Introduction}

Aerosol particles can be directly emitted into the atmosphere from natural and anthropogenic sources (primary aerosols) or can be produced by gas-to-particle conversion processes (secondary aerosols). They affect the regional and global climate by absorbing and scattering light and by acting as cloud condensation nuclei (CCN) and ice nuclei (IN). Although physical and chemical properties of atmospheric aerosol particles have been widely studied, large uncertainties remain, both in their direct and indirect climate effects (IPCC, 2013). Hygroscopicity, the ability of particles to take up water, is important when considering aerosol climate effects. Hygroscopicity of a particle is defined by the particle's composition; therefore, hygroscopicity can be used for indirectly estimating chemical composition of size-resolved nanoparticles (Riipinen et al., 2009; Ristovski et al., 2010; Sakurai et al., 2005).

Experimental and theoretical studies have shown that sulfuric acid is an important ingredient in particle formation (Kulmala et al., 2004; Weber et al., 1997). It has also been shown that new particle formation in the boundary layer cannot be explained by pure sulfuric acid-water nucleation (Kirkby et al., 2011). Other compounds such as ammonia and/or organics are needed to explain observed atmospheric particle formation and growth, and have thus been widely studied. Much of the recent focus has been on the effect of amines on particle formation. Both experimental and computational studies have indicated that amines enhance particle formation significantly more than ammonia (Almeida et al., 2013; Barsanti et al., 2009; Berndt et al., 2010; Bzdek et al., 2010; Erupe et al., 2011; Kurtén et al., 2008; Kürten et al., 2014; Loukonen et al., 2010; Paasonen et al., 2012; Pratt et al., 2009; Zhao et al., 2011). Moreover, alkylaminium salts in atmospheric particles with sizes of $8-10 \mathrm{~nm}$ have been observed during new-nanoparticle-formation events (Smith et al., 2010). Still, physicochemical properties of nanoparticles produced by homogeneous nucleation of amines with sulfuric acid-water and their subsequent growth are not yet well understood.

Both laboratory experiments and field observations have shown that organic compounds play important roles in atmospheric particle formation and growth and make up a large fraction of the submicron aerosol mass (Hallquist et al., 2009; Jimenez et al., 2009; Metzger et al., 2010; Riccobono et al., 2014). Most chamber studies have focused either on secondary organic aerosol (SOA) mass yields or on identifying and quantifying the compounds produced from oxidation (Griffin et al., 1999; Hao et al., 2011; Hennigan et al., 2011; Kroll et al., 2005). Chemical aging processes with various oxidants have also been studied (Donahue et al., 2012; Henry and Donahue, 2012; Henry et al., 2012; Pierce et al., 2011; Yasmeen et al., 2012). Several useful studies also have been performed on the hygroscopic properties of SOA produced either in the laboratory or in the atmosphere, including the effect of the oxygen-to-carbon $(\mathrm{O}: \mathrm{C})$ ratio on hygroscopicity (Chang et al., 2010; Duplissy et al., 2011; Engelhart et al., 2008; Frosch et al., 2011; Jimenez et al., 2009; Lambe et al., 2011; Massoli et al., 2010; Roberts et al., 2010; Sjogren et al., 2008; Varutbangkul et al., 2006; Virkkula et al., 1999). Jimenez et al. (2009) and Duplissy et al. (2011) found that the hygroscopicity of SOA increased with increasing oxidation level at subsaturated conditions (ca. 90-95\% relative humidity (RH)), while Frosch et al. (2011) showed that the relationship between the hygroscopicity of particles with diameters in the $59-200 \mathrm{~nm}$ range and an $\mathrm{O}: \mathrm{C}$ ratio in the 0.3-0.6 range was weak at supersaturated conditions. Massoli et al. (2010) reported that the hygroscopicity parameter increased with oxidation level both in subsaturated and supersaturated conditions. Although many studies on physical and chemical properties of SOA have been performed, there are still significant gaps in our understanding of the detailed initial growth pathways, and of the properties of freshly nucleated nanoparticles.

In this study, we focus on determining the hygroscopicity of nanoparticles generated by homogeneous nucleation of sulfuric acid with organic compounds such as dimethylamine and $\alpha$-pinene oxidation products in the Cosmics Leaving OUtdoor Droplets (CLOUD) chamber at CERN. The measurements were performed with a nanometer-hygroscopicity tandem differential mobility analyzer (nano-HTDMA) (Keskinen et al., 2011) during the CLOUD7 experiments. Vol- 
ume fractions of inorganic sulfates and dimethylamine sulfate (DMAS) in the nanoparticles were estimated from nano-HTDMA results and the Zdanovskii-Stokes-Robinson (ZSR) relation (Choi and Chan, 2002; Kim et al., 2011; Meyer et al., 2009; Petters and Kreidenweis, 2007). Moreover, simulation results from the thermodynamic phase equilibrium model E-AIM (Extended Aerosol Inorganics Model; Clegg et al., 1992; Ge et al., 2011; Wexler and Clegg, 2002; http://www.aim.env.uea.ac.uk/aim/aim.php) were combined to provide further information on chemical properties of nucleated nanoparticles.

\section{Experimental methods}

\subsection{CLOUD chamber}

The experiments were carried out with the CLOUD chamber at CERN, which has been described by Kirkby et al. (2011), Almeida et al. (2013) and Duplissy et al. (2015). In brief, the CLOUD chamber is a cylindrical electropolished stainlesssteel tank with a volume of $26.1 \mathrm{~m}^{3}$. An ultraviolet (UV) light system which can control the aperture of the UV light (Kupc et al., 2011) and two stainless-steel fans for mixing vapors (Voigtländer et al., 2012) are installed in the chamber. During CLOUD7 experiments, temperature and relative humidity in the chamber were constant at $278 \mathrm{~K}( \pm 0.5 \mathrm{~K})$ and $38 \%( \pm 1 \%)$, respectively. The experiments were classified into three groups depending on the nucleation conditions: neutral $(N)$, ground-level galactic cosmic rays (GCRs), and charged pion beam $(\pi)$. In the neutral nucleation experiments, small ions in the chamber were removed with electric fields $( \pm 20 \mathrm{kV})$. The chamber was exposed to a positively charged pion beam (Duplissy et al., 2010) during the charged-pion-beam nucleation experiments, whereas no electric clearing fields and no pion beam were used under GCR conditions. Precursor vapors such as sulfur dioxide $\left(\mathrm{SO}_{2}\right)$, dimethylamine $\left(\left(\mathrm{CH}_{3}\right)_{2} \mathrm{NH}\right)$, and $\alpha$-pinene $\left(\mathrm{C}_{10} \mathrm{H}_{16}\right)$ were continuously provided into the CLOUD chamber to produce particles.

Size distributions of particles produced in the chamber were continuously monitored with a scanning mobility particle sizer (SMPS). The sulfuric acid concentration was measured using a chemical ionization mass spectrometer (CIMS) (Kürten et al., 2011); concentrations of dimethylamine, ammonia, and $\alpha$-pinene were observed with a proton transfer reaction time-of-flight mass spectrometer (PTR-TOF-MS) (Schnitzhofer et al., 2014). The concentrations of $\mathrm{SO}_{2}$ and $\mathrm{O}_{3}$ were also continuously measured by an $\mathrm{SO}_{2}$ detector (42i-TLE, Thermo Fisher Scientific, Inc.) and an $\mathrm{O}_{3}$ monitor (TEI 49C, Thermo Environmental Instruments), respectively. The detailed experimental conditions performed in this study can be seen in Table 1.

\subsection{Nano-HTDMA}

The nano-HTDMA system (Keskinen et al., 2011) was applied to determine the hygroscopic growth of nucleated nanoparticles at a constant subsaturated relative humidity. It consisted of two different mobility analyzers (DMA1 and DMA2; TSI 3085, USA) (Chen et al., 1998), an aerosol humidifier, and a condensation particle counter (CPC; TSI 3785, USA), as shown in Fig. 1. The TDMA measurement technique has been described in previous studies (McMurry and Stolzenburg, 1989; Hämeri et al., 2000; Sakurai et al., 2005). Briefly, nanoparticles generated in the CLOUD chamber were dried to about 10-15\% RH and then passed through a bipolar diffusion charger $\left({ }^{85} \mathrm{Kr}\right.$, TSI) before entering the nano-HTDMA system. The nanoparticles with a certain electrical mobility were classified from charged polydisperse aerosols by DMA1. The RH of aerosol sample after passing through DMA1 was $\sim 4.5 \%$. The selected nanoparticles passed through the aerosol humidifier made out of GoreTex tubing with a $5 \mathrm{~s}$ residence time at the targeted $\mathrm{RH}$. This residence time should be enough for the particles to reach their equilibrium GF (Duplissy et al., 2009). The RH of the aerosol flow, the sheath air, and the excess air in DMA2 were continuously monitored using capacitive RH sensors (Vaisala model HMP 110). The RH was kept constant to within $1.5 \%$ of the set values. After humidifying, the size and number concentration of the particles were measured with DMA2 and the CPC to determine the change in particle size due to interaction with water vapor. Based on these results, lognormal number size distributions were fitted to the distributions to estimate the geometric mean diameter (GMD) with a standard DMA data inversion algorithm (Reischl, 1991). The use of GMD is relevant for this study as the sampled aerosol was internally mixed. In this study, the measurements were performed at $90 \pm 1.5 \% \mathrm{RH}$ for 10 and $15 \mathrm{~nm}$ particles. The flow rate of the aerosol sample was $1 \mathrm{~L} \mathrm{~min}^{-1}$. The ratio of sample aerosol flow to sheath air flow of the DMA was $1: 10$. The size and RH calibration of the nano-HTDMA was carried out by using ammonium sulfate nanoparticles before, during, and after the CLOUD7 experiments. The RH calibration was done by measuring the efflorescence and deliquescence RH of ammonium sulfate particles and by comparing the values to the theoretical values.

\section{Data analysis and theory}

\subsection{Hygroscopic growth factor and hygroscopicity parameter $\kappa$}

The hygroscopic growth factor (HGF) is a measure of the diameter growth of the size-selected particles at a certain RH compared with dry conditions and is defined as

$\mathrm{HGF}=\frac{d_{\mathrm{p}, \mathrm{GMD}}(\mathrm{RH})}{d_{\mathrm{p}, \mathrm{GMD}}(\text { dry })}$, 
Table 1. Summary of the experimental conditions. The experiments were performed in the presence of sulfuric acid (Exp. A), sulfuric acid and dimethylamine (Exps. B-D), and sulfuric acid and organics produced from $\alpha$-pinene ozonolysis $(\mathrm{Exps} \mathrm{E}-\mathrm{F}) . \mathrm{H}_{2} \mathrm{SO}_{4},\left(\mathrm{CH}_{3}\right)_{2} \mathrm{NH}_{\text {, }}$ $\mathrm{C}_{10} \mathrm{H}_{16}$, and $\mathrm{O}_{3}$ refer to gas concentrations of sulfuric acid, dimethylamine, $\alpha$-pinene, and ozone, respectively. Here the error in the HGF values indicates the standard deviation for the measured results. UV aperture indicates UV lamp aperture opening (in \%), which in turn provides different UV intensities inside the chamber (Kupc et al., 2011).

\begin{tabular}{|c|c|c|c|c|c|c|c|c|}
\hline \multirow[t]{2}{*}{ No. } & \multirow[t]{2}{*}{ Experiments } & \multirow{2}{*}{$\begin{array}{r}\mathrm{H}_{2} \mathrm{SO}_{4} \\
\left(10^{6} \text { molecules } \mathrm{cm}^{-3}\right)\end{array}$} & \multirow{2}{*}{$\begin{array}{r}\left(\mathrm{CH}_{3}\right)_{2} \mathrm{NH} \\
(\mathrm{ppt})\end{array}$} & \multirow{2}{*}{$\begin{array}{r}\mathrm{C}_{10} \mathrm{H}_{16} \\
(\mathrm{ppt})\end{array}$} & \multirow{2}{*}{$\begin{array}{r}\mathrm{O}_{3} \\
(\mathrm{ppb})\end{array}$} & \multirow{2}{*}{$\begin{array}{r}\text { UV aperture } \\
(\%)\end{array}$} & \multicolumn{2}{|c|}{ HGF } \\
\hline & & & & & & & $10 \mathrm{~nm}$ & $15 \mathrm{~nm}$ \\
\hline $\mathrm{A}$ & Sulfuric acid & 35.2 & 0 & 0 & 23.5 & 100 & $1.55 \pm 0.02$ & $1.56 \pm 0.02$ \\
\hline B & Sulfuric acid-dimethylamine & 5.1 & 11.8 & 0 & 23.5 & 20 & $1.49 \pm 0.01$ & $1.36 \pm 0.01$ \\
\hline $\mathrm{C}$ & Sulfuric acid-dimethylamine & 7.6 & 23.8 & 0 & 23.5 & 40 & $1.50 \pm 0.01$ & $1.45 \pm 0.01$ \\
\hline $\mathrm{D}$ & Sulfuric acid-dimethylamine & 12.3 & 23.8 & 0 & 23.5 & 100 & $1.50 \pm 0.02$ & $1.47 \pm 0.02$ \\
\hline $\mathrm{E}$ & Sulfuric acid-organics I & 15.1 & 0 & 420 & 22.5 & 0 & $1.35 \pm 0.01$ & $1.33 \pm 0.02$ \\
\hline $\mathrm{F}$ & Sulfuric acid-organics II & 19.4 & 0 & 910 & 23.0 & 0 & $1.31 \pm 0.01$ & $1.29 \pm 0.01$ \\
\hline
\end{tabular}

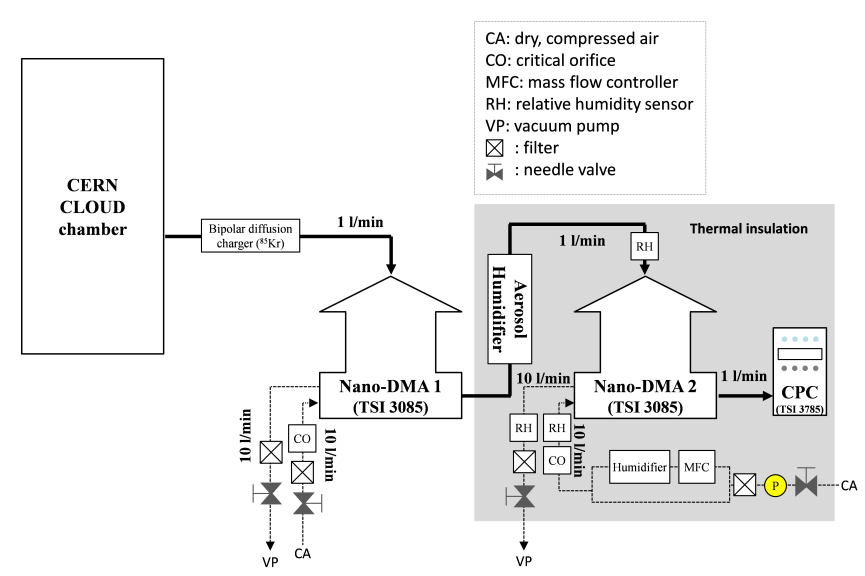

Figure 1. A schematic drawing of the nano-TDMA system used in this study.

where $d_{\mathrm{p}, \mathrm{GMD}}(\mathrm{RH})$ is the GMD of the particles at the elevated RH (ca. 90\%) and $d_{\mathrm{p}, \mathrm{GMD}}$ (dry) is the GMD for particles at dry conditions $(\sim 4.5 \% \mathrm{RH})$.

In many cases it is useful to represent hygroscopic properties with a single hygroscopicity parameter $\kappa$, defined by Petters and Kreidenweis (2007) as

$\kappa=\left(\mathrm{HGF}^{3}-1\right)\left(\frac{K_{e}}{S}-1\right)$,

where $S$ is the saturation ratio $\left(S=\frac{\mathrm{RH}}{100}\right)$ and $K_{e}$ the Kelvin factor, defined as

$K_{e}=\exp \left(\frac{4 M_{\mathrm{w}} \sigma_{\mathrm{w}}}{R T \rho_{\mathrm{w}} d_{\mathrm{p}}}\right)$.

Here $M_{\mathrm{w}}$ is the molecular weight of water, $\sigma_{\mathrm{w}}$ the surface tension of the water, $R$ the ideal gas constant, $T$ the temperature, $\rho_{\mathrm{w}}$ the density of water, and $d_{\mathrm{p}}$ the diameter after humidification $\left(d_{\mathrm{p}, \mathrm{GMD}}(\mathrm{RH})=d_{\mathrm{p}, \mathrm{GMD}}(\mathrm{dry}) \times \mathrm{HGF}\right)$. The $\kappa$ values are in the range of 0 for insoluble particles such as black carbon to larger than 1 for water-soluble salt particles (Jurányi et al., 2009; Petters and Kreidenweis, 2007).
In order to obtain indirect chemical composition information from the nano-HTDMA results in experiments B-D (Table 1), we use the ZSR relation, which assumes that the water uptake volume of a mixture is the independent sum of the water uptake volume of each individual component. The organic volume fraction can then be estimated by assuming a two-component system consisting of organic and inorganic sulfate as (Keskinen et al., 2013)

$\varepsilon_{\text {DMAS }}=\frac{\left(\kappa-\kappa_{\text {inorg }}\right)}{\left(\kappa_{\text {DMAS }}-\kappa_{\text {inorg }}\right)}$,

where $\kappa$ is the hygroscopicity obtained from the nanoHTDMA measurements and $\kappa_{\text {DMAS }}$ and $\kappa_{\text {inorg }}$ are the hygroscopicity parameters for DMAS and inorganic sulfates, respectively. Although ammonia was not injected into the chamber during these experiments, measurements by the Thermal Desorption Chemical Ionization Mass Spectrometer (TDCIMS; Smith et al., 2004) showed that ammonium is a significant constituent of $5-20 \mathrm{~nm}$ particles during these new-particle-formation events (Lawler et al., 2016). Therefore, we calculated the DMAS volume fraction by assuming that the inorganic sulfates in the particles are either sulfuric acid or ammonium sulfate. Keskinen et al. (2013) showed that the hygroscopic properties of particles at a diameter of $150 \mathrm{~nm}$ in the presence of sulfuric acid and ammonia are in good agreement with theoretical predictions of ammonium

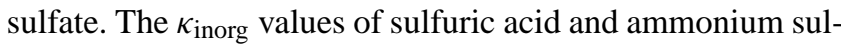
fate were assumed as 0.70 (Sullivan et al., 2010) and 0.47 (Topping et al., 2005), respectively. The $\kappa_{\text {DMAS }}$ was assumed as 0.28 derived from hygroscopic growth factors for dry diameters 80-240 nm measured by Qiu and Zhang (2012).

\subsection{Thermodynamic equilibrium modeling}

The E-AIM was used to estimate the molecular ratio of bases and acids for particles consisting of sulfuric acid, dimethylamine, and ammonia. In the model, acid deprotonation and base protonation are taken into account in the aqueous phase. Sulfuric acid is a strong acid and is assumed to deprotonate 
at least singly when present in aqueous solutions. It may also deprotonate a second time to form sulfate ions. Dimethylamine and ammonia are bases that have a single protonation product. Mole fractions of the deprotonated acids and protonated bases are estimated using the acid dissociation constants of the compounds defined in E-AIM (Ge et al., 2011). The density of the aqueous solution in the model is parameterized according to Clegg et al. (2013), and the surface tension is obtained from measurements by Hyvärinen et al. (2004). The E-AIM does not take into account the surface curvature of particles. Thus, when estimating the water uptake of a nanoparticle with a certain dry size and composition, the equilibrium vapor pressure for water vapor obtained from E-AIM needs to be corrected for the Kelvin effect by multiplication with the Kelvin term, which requires iterating to find the equilibrium.

Based on the TDCIMS observation (Lawler et al., 2016), we assumed that particles consisted of sulfuric acid, dimethylamine, and ammonia and that the base in the particle consisted of $50 \%$ dimethylamine and $50 \%$ ammonia. Also, we assumed that no particle evaporation took place in the sampling lines or in the instrument. The assumption was tested by modelling the particle evaporation in the sampling lines and inside the HTDMA, and based on the model results the evaporation was negligible (Ahlm et al., 2016). By calculating the water uptake (and the resulting HGF) in E-AIM for particles of different base / acid molecular ratios, the composition of the particles could be estimated.

\section{Results and discussion}

\subsection{The role of dimethylamine- or $\alpha$-pinene-related secondary organic compounds in the hygroscopicities of nucleated nanoparticles}

In this section, the role of dimethylamine or secondary organic compounds from the oxidation of $\alpha$-pinene in defining the hygroscopicities of nanoparticles is investigated (Exps. A and D-F). The concentrations of sulfuric acid, dimethylamine, and $\alpha$-pinene in the chamber for the different experiments are shown in Table 1 . The $\kappa$ values of 10 and $15 \mathrm{~nm}$ particles produced by sulfuric acid, sulfuric aciddimethylamine, and sulfuric acid-organics are shown in Fig. 2. In Exp. A, the hygroscopicities of particles in the presence of sulfuric acid only were examined. The $\kappa$ values ( \pm standard deviation) of nucleated nanoparticles were $0.64 \pm 0.02$ and $0.52 \pm 0.02$ for 10 and $15 \mathrm{~nm}$, respectively (the HGF of 10 and $15 \mathrm{~nm}$ particles were $1.55 \pm 0.02$ and $1.56 \pm 0.02$, as shown in Table 1). Here the error bars represent the standard deviation of the measurements from the mean value. The $\kappa$ values are slightly lower than previous results for sulfuric acid $\left(\kappa_{\mathrm{H}_{2} \mathrm{SO}_{4}} \sim 0.7\right)$ reported elsewhere (Shantz et al., 2008; Sullivan et al., 2010). Also, the the-

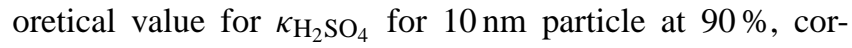

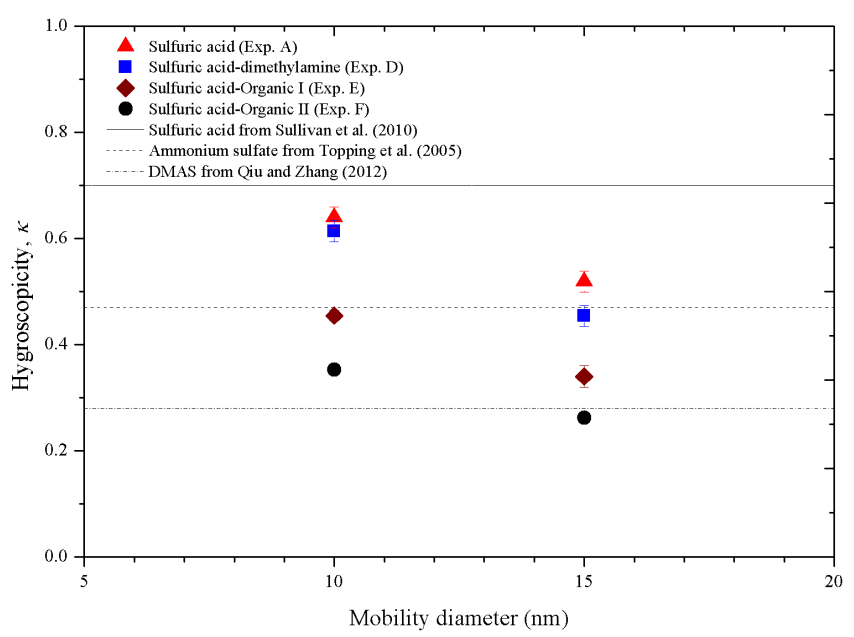

Figure 2. Comparison of the hygroscopicity $(\kappa)$ for 10 and $15 \mathrm{~nm}$ particles in the presence of sulfuric acid (Exp. A), sulfuric aciddimethylamine (Exp. D), and sulfuric acid-organics produced by $\alpha$-pinene oxidation with $\mathrm{OH}$ scavenger (Exps. E-F). The theoretical $\kappa$ of sulfuric acid (solid line) from Sullivan et al. (2010), $\kappa$ of ammonium sulfate (dashed line) from Topping et al. (2005), and $\kappa$ of DMAS (dashed dotted line) from Qiu and Zhang (2012) are also presented. The $\alpha$-pinene concentrations during sulfuric acidorganic I and sulfuric acid-organic II were 420 and 910 ppt, respectively, as can be seen in Table 1. Error bars show a standard deviation from measurements data.

responding to our experimental conditions (residual water taken into account) and calculated by E-AIM, is 0.7 (at $90 \%$ $\mathrm{RH}$ ). In should be noted that the sulfuric acid solution droplet is highly unideal. Hence, the calculated $\kappa$ value from EAIM depends strongly on both humidity and particle size. The reason for the lower measured $\kappa$ values of the nucleated nanoparticles can be twofold: (1) existence of trace levels of contaminants such as ammonia and dimethylamine in the chamber and/or (2) residual water in the nanoparticle after passing through DMA1. Although we supplied only sulfuric acid to the chamber and an overnight cleaning cycle $\left(100^{\circ} \mathrm{C}\right.$ for $12 \mathrm{~h}$ ) was performed to remove contaminants before experiments, the atmospheric pressure interface time-of-flight mass spectrometer (APi-TOF) measurements showed that trace levels of ammonia and dimethylamine still remained in the clusters $(<2 \mathrm{~nm})$ (Bianchi et al., 2014), most probably due to wall adsorption from previous experiments. Ammonia and dimethylamine were also found in the nanoparticles $(<40 \mathrm{~nm})$ from TDCIMS measurements (Lawler et al., 2016). This observation suggests that trace levels of these ammonia and dimethylamine in the chamber may be present in the nucleated nanoparticles, hence decreasing the $\kappa$ values.

The hygroscopic properties of nucleated nanoparticles in the presence of sulfuric acid and dimethylamine were determined in Exp. D. Although dimethylamine was continuously supplied into the chamber to maintain a concentration of $23.8 \mathrm{ppt}$, the observed $\kappa$ values for $10 \mathrm{~nm}$ particles 
agree to within $4 \%$ with the results for particles in the presence of sulfuric acid, as can be seen in Fig. 2. In the case of the $15 \mathrm{~nm}$ particles, however, the hygroscopicities of sulfuric acid-dimethylamine particles were $12 \%$ lower than those for sulfuric acid particles. This decline of hygroscopicity for $15 \mathrm{~nm}$ particles is probably caused by an increasing amount of aminium salts during the growth process. The E-AIM model results show that the observed decreases in $\kappa$ values could be explained by decreasing particle acidity with increasing particle size, as shown in Table 2 . Our results indicate that the ratio of dimethylamine to sulfuric acid increases when particles grow from 10 to $15 \mathrm{~nm}$. It should be noted that the monodisperse particle growth model MABNAG (Model for Acid-Base chemistry in NAnoparticle Growth) predicts lower acidity in the 10 and $15 \mathrm{~nm}$ particles than do the HTDMA-based estimates under the same experimental conditions (Ahlm et al., 2016). The reason for this discrepancy is still unknown; it may be related to measurement uncertainties in the $10-15 \mathrm{~nm}$ size range, or to the incomplete understanding of the growth process of particles formed from sulfuric acid and dimethylamine. Chan and Chan (2013) observed evaporation of dimethylamine from aminium sulfate particles upon drying at $3 \% \mathrm{RH}$ using an electrodynamic balance. Ouyang et al. (2015) also concluded that dry particles consisting of dimethylamine and sulfuric acid in the size range of $5-8.5 \mathrm{~nm}$ would be unstable under ambient conditions. In our HTDMA measurements the particles were dried before measuring the growth factor; therefore some of the dimethylamine may have evaporated from the particles prior to growth factor measurements, increasing the acidity of the particles. Based on the thermodynamic condensation model simulation, the base / acid molar ratio may have decreased in the sampling line as much as $15 \%$ (in the experiment with 40 ppt of dimethylamine) (Ahlm et al., 2016) compared to the value in the chamber. However, the difference between the base/acid ratio of growing particles predicted with the model and that derived from measured growth factors is much larger than this. It is, therefore, unlikely that evaporation of dimethylamine alone would explain this discrepancy.

We also investigated the hygroscopicities of nanoparticles produced in the chamber in the presence of $\alpha$-pinene, sulfuric acid, and $\mathrm{O}_{3}$ (Exps. $\mathrm{E}$ and $\mathrm{F}$ ). In these experiments, hydrogen $\left(\mathrm{H}_{2}\right)$ was added to suppress $\mathrm{OH}$ radicals from $\alpha$ pinene ozonolysis in order to probe the role of ozonolysis alone on new particle formation (Praplan et al., 2015). Although the concentrations of sulfuric acid were higher during the sulfuric acid-organics experiments than during the sulfuric acid-dimethylamine experiments, the HGFs of particles in the presence of sulfuric acid and organics were much smaller than those of particles in the presence of sulfuric acid and dimethylamine, as can be seen in Table 1. As shown in Fig. 2, the hygroscopicity of $10 \mathrm{~nm}$ particles when $\alpha$-pinene ozonolysis products are present is significantly lower than observed in the sulfuric acid or sulfuric acid-dimethylamine
Table 2. Molecular ratio of base to acid compounds from the EAIM model, assuming no evaporation of dimethylamine from the particles. The E-AIM results were derived from the HGF results of particles. Based on TDCIMS measurements, we assumed that the acid compound is only sulfuric acid and that base compounds consist of $50 \%$ ammonia and $50 \%$ dimethylamine in the particles.

\begin{tabular}{llcr}
\hline No. & Experiments & $\begin{array}{l}\text { Molecular ratio (base / acid) } \\
10 \mathrm{~nm}\end{array}$ & $15 \mathrm{~nm}$ \\
\hline A & Sulfuric acid & - & 0.7 \\
D & Sulfuric acid-dimethylamine & 0.3 & 1.0 \\
\hline
\end{tabular}

experiments; moreover it decreases with increasing size. It has previously been reported that the hygroscopicity of organics from $\alpha$-pinene oxidation is clearly lower than the hygroscopicity of sulfuric acid (or ammonia-containing sulfate compounds) (Qiu and Zhang, 2012; Massoli et al., 2010). Hence, the present results indicate that the organic-oxidation products contribute significantly to the composition of both 10 and $15 \mathrm{~nm}$ particles and, thereby, to their growth.

\subsection{The effect of the sulfuric acid concentration on the hygroscopicity of particles in the presence of sulfuric acid and dimethylamine}

We also investigated the effect of sulfuric acid concentration on the hygroscopicity of 10 and $15 \mathrm{~nm}$ particles (Exps. B-D); while $\mathrm{SO}_{2}$ and dimethylamine were continuously added to the chamber at a constant rate, the UV light intensity was varied by changing the light aperture. The sulfuric acid monomer concentrations at an aperture of 20,40 , and $100 \% \mathrm{UV}$ were $5.1 \times 10^{6}, 7.6 \times 10^{6}$, and $12.3 \times 10^{6}$ molecules $\mathrm{cm}^{-3}$, respectively; in the discussion that follows we will refer to these concentrations as low, medium, and high, respectively. The growth rate (GR) of particles from 4 to $15 \mathrm{~nm}$ diameter increases from 2.35 to $8.41 \mathrm{~nm} \mathrm{~h}^{-1}$ with increasing sulfuric acid concentration from $5.1 \times 10^{6}$ to $12.3 \times 10^{6}$ molecules $\mathrm{cm}^{-3}$. The large increase in the GR is probably due to a combination of the enhanced kinetic condensation of sulfuric acid (and dimethylamine) molecules and the increase in the number concentration of the formed particles, enhancing growth by coagulation (Ahlm et al., 2016). However, there were no remarkable differences among the hygroscopicities of $10 \mathrm{~nm}$ particles, as shown in Fig. 3a. The $\kappa$ values ( \pm standard deviation) of the $10 \mathrm{~nm}$ particles were $0.58 \pm 0.01,0.60 \pm 0.01$, and $0.61 \pm 0.02$ for low, medium, and high sulfuric acid concentrations, respectively. This suggests that the composition of $10 \mathrm{~nm}$ particles does not change significantly over this range of sulfuric acid and dimethylamine gas-phase concentrations.

In contrast to the insensitivity of hygroscopicity for $10 \mathrm{~nm}$ particles to sulfuric acid levels, the hygroscopicity of $15 \mathrm{~nm}$ particles increases with increasing gas-phase sulfuric acid 


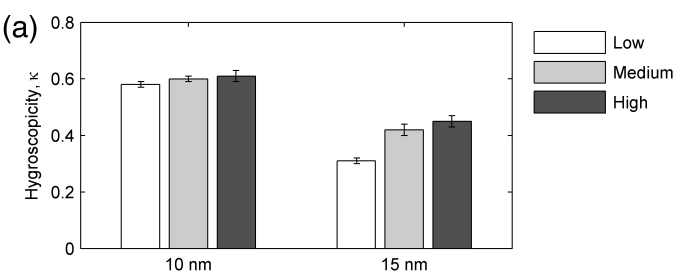

(b)
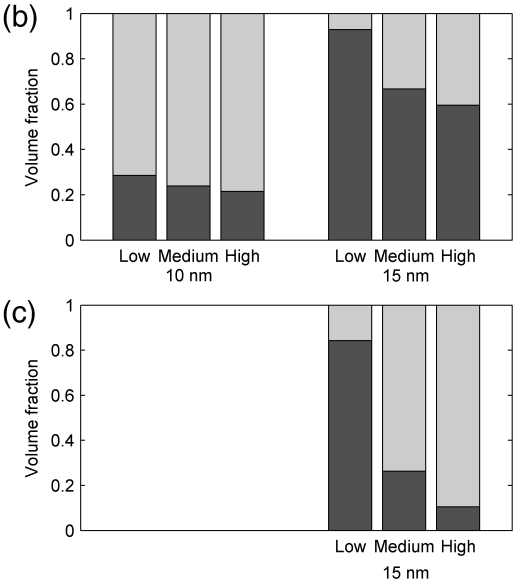

Figure 3. (a) Comparison of hygroscopicity of 10 and $15 \mathrm{~nm}$ particles produced from sulfuric acid and dimethylamine. (b-c) Estimated volume fractions in the particles depending on UV aperture (Exps. B-D) assuming the inorganic fraction was (b) sulfuric acid and had a hygroscopicity $\kappa=0.70$ and (c) ammonium sulfate and had a hygroscopicity $\kappa=0.47$. The concentrations of sulfuric acid were $5.1 \times 10^{6}, 7.6 \times 10^{6}$, and $12.3 \times 10^{6}$ molecules $\mathrm{cm}^{-3}$ for low, medium, and high, respectively.

(i.e., with increasing UV intensity). The $\kappa$ values ( \pm standard deviation) were $0.31 \pm 0.01,0.42 \pm 0.02$, and $0.45 \pm 0.02$ for low, medium, and high sulfuric acid concentrations, respectively. Especially, the $\kappa$ value for the low gas-phase sulfuric acid concentration was close to that of DMAS at $90 \% \mathrm{RH}$ ( $\left.\kappa_{\text {DMAS }} \sim 0.28\right)($ Qiu and Zhang, 2012). This suggests that more aminium salts were involved in $15 \mathrm{~nm}$ particles with decreasing gas-phase sulfuric acid concentrations. The DMAS volume fractions ( \pm standard deviation) derived from Eq. (4) using experimentally derived sulfuric acid hygroscopicity for the inorganic sulfate $\left(\kappa_{\text {inorg }}=0.70\right)$ varied from $0.29 \pm 0.03$ to $0.20 \pm 0.05$ for $10 \mathrm{~nm}$ particles and from $0.92 \pm 0.02$ to $0.58 \pm 0.03$ for $15 \mathrm{~nm}$ particles depending on the gas-phase sulfuric acid concentrations (Fig. 3b). Due to the observation of ammonia in the particles the DMAS volume fraction in $10 \mathrm{~nm}$ particles was also calculated assuming that the inorganic fraction was ammonium sulfate $\left(\kappa_{\text {inorg }}=0.47\right)$ to investigate how much the uncertainty in inorganic composition can affect the calculations. This assumption resulted in lower DMAS volume fractions for $15 \mathrm{~nm}$ particles compared to the assumption of inorganic sulfate being sulfuric acid (Fig. 3c). The measured $\kappa$ of $10 \mathrm{~nm}$ particles were too high to be explained with a combination of ammonium sul- fate and DMAS. In summary, with each value of $\kappa_{\text {inorg }}$ there is a clear increase in the DMAS volume fraction from 10 to $15 \mathrm{~nm}$. Hence our measurements support the view that the contribution of dimethylamine to particle growth increases with increasing particle size.

\section{Summary and conclusions}

The hygroscopic properties of nucleated nanoparticles in the presence of sulfuric acid, sulfuric acid-dimethylamine, and sulfuric acid combined with organics derived from $\alpha$-pinene ozonolysis were investigated with the nano-HTDMA. The hygroscopicities decreased with increasing particle size, consistent with a decrease of particle acidity with increased particle size. The obtained hygroscopicity parameter $(\kappa)$ values of $10 \mathrm{~nm}$ particles in the presence of sulfuric aciddimethylamine were similar to those of particles in the presence of sulfuric acid with trace levels of contaminants within $4 \%$ (the $\kappa$ values of sulfuric acid-dimethylamine and sulfuric acid were $0.61 \pm 0.02$ and $0.64 \pm 0.02$, respectively). For $15 \mathrm{~nm}$ particles, however, the hygroscopicities of sulfuric acid-dimethylamine particles were lower by $12 \%$ compared to the results for the sulfuric acid particles. This finding suggests that the contribution of dimethylamine to growth increases as the particles grow from 10 to $15 \mathrm{~nm}$. In the presence of sulfuric acid and organics, the HGFs were much smaller than in the presence of sulfuric acid and dimethylamine regardless of the sulfuric acid concentration. This is because the hygroscopicities of organics derived from $\alpha$-pinene oxidation were smaller than those of dimethlyaminium sulfate (generally the hygroscopicity of $\alpha$ pinene-derived organic material is close to a value of 0.1 ; see e.g. Pajunoja et al., 2015) and/or $\alpha$-pinene oxidation products contributed more to the particles mass. In contrast to the sulfuric acid-dimethylamine experiments, the hygroscopicities of $10 \mathrm{~nm}$ particles in sulfuric acid-organic experiments were clearly lower than in the sulfuric acid experiments; moreover, the hygroscopicity decreased with increasing size, indicating that the organic compounds are able to contribute significantly to growth and composition of both 10 and $15 \mathrm{~nm}$ particles. This is probably due to the very low saturation vapor pressures of organic compounds produced from $\alpha$-pinene oxidation (Ehn et al., 2014).

Acknowledgements. We would like to thank CERN for supporting CLOUD with important technical and financial resources, and for providing a particle beam from the CERN Proton Synchrotron. We also thank P. Carrie, L.-P. De Menezes, J. Dumollard, F. Josa, I. Krasin, R. Kristic, A. Laassiri, O. S. Maksumov, B. Marichy, H. Martinati, S. V. Mizin, R. Sitals, A. Wasem, and M. Wilhelmsson for their important contributions to the experiment. We thank the CSC Centre for Scientific Computing in Espoo, Finland, for computer time. This research has received funding from the EC Seventh Framework Programme (Marie Curie Initial Training Network 
CLOUD-ITN no. 215072, MC-ITN CLOUD-TRAIN no. 316662 , ERC Starting Grant MOCAPAF no. 57360, ERC Consolidator Grant NANODYNAMITE no. 616075, ERC Advanced Grant ATMNUCLE no. 227463, and ERC Starting Grant "QAPPA" grant no. 335478); the German Federal Ministry of Education and Research (project nos. 01LK0902A and 01LK1222A); the Swiss National Science Foundation (project nos. 200020 135307, 200021 140663, 206021 144947/1, 20FI20 149002/1, and 200021 140663); the Academy of Finland Centre of Excellence program (project no. 1118615); the Academy of Finland (135054, 133872, 251427, 1389515, 139656, 139995, 137749, 141217, 141451, 2720541, 259005, 264989); the Finnish Funding Agency for Technology and Innovation; the Nessling Foundation; the Strategic Funding from University of Eastern Finland; the Austrian Science Fund (FWF; project no. P19546 and L59321); the Portuguese Foundation for Science and Technology (project no. CERN/FP/116387/ 2010); the Swedish Research Council, Vetenskapsrådet (grant 2011-5120); the Presidium of the Russian Academy of Sciences and Russian Foundation for Basic Research (grants 08-02-91006-CERN and 12-02-91522-CERN); the U.S. National Science Foundation (grants AGS1136479 and CHE1012293); a Davidow Grant to Caltech's Global Environmental Science Program; Dreyfus Award EP-11-117; the French National Research Agency (ANR); the Nord-Pas de Calais; the European Funds for Regional Economic Development (FEDER, Labex-Cappa, ANR-11-LABX-0005-01); and the French Civil Aviation Office (MERMOSE).

Edited by: H. Su

\section{References}

Ahlm, L., Yli-Juuti, T., Schobesberger, S., Praplan, A. P., Kim, J., Tikkanen, O. -P, Lawler, M. J., Smith, J. N., Tröstl, J., Acosta Navarro, J. C., Baltensperger, U., Bianchi, F., Donahue, N. M., Duplissy, J., Franchin, A., Jokinen, T., Keskinen, H., Kürten, A., Laaksonen, A., Lehtipalo, K., Petäjä, T., Riccobono, F., Rissanen, M. P., Rondo, L., Schallhart, S., Simon, M., Winkler, P. M., Worsnop, D. R., Virtanen, A., and Riipinen, I.: Modeling the thermodynamics and kinetics of sulfuric acid-dimethylaminewater nanoparticle growth in the CLOUD chamber, Aerosol Sci. Technol., in review, 2016.

Almeida, J., Schobesberger, S., Kürten, A., Ortega, I. K., Kupiainen, O., Praplan, A., Adamov, A., Amorim, A., Bianchi, F., Breitenlechner, M., David, A., Dommen, J., Donahue, N. M., Downard, A., Dunne, E., Duplissy, J., Ehrhart, S., Flagan, R. C., Franchin, A., Guida, R., Hakala, J., Hansel, A., Heinritzi, M., Henschel, H., Jokinen, T., Junninen, H., Kajos, M., Kangasluoma, J., Keskinen, H., Kupc, A., Kurtén, T., Kvashin, A., Laaksonen, A., Lehtipalo, K., Leiminger, M., Leppä, J., Loukonen, V., Makhmutov, V., Mathot, S., McGrath, M. J., Nieminen, T., Olenius, T., Onnela, A., Petäjä, T., Riccobono, F., Riipinen, I., Rissanen, M., Rondo, L., Ruuskanen, T., Santos, F. D., Sarnela, N., Schallhart, S., Schnitzhofer, R., Seinfeld, J. H., Simon, M., Sipilä, M., Stozhkov, Y., Stratmann, F., Tomé, A., Tröstl, J., Tsagkogeorgas, G., Vaattovaara, P., Viisanen, Y., Virtanen, A., Vrtala, A., Wagner, P. E., Weingartner, E., Wex, H., Williamson, C., Wimmer, D., Ye, P., Yli-Juuti, T., Carslaw, K., Kulmala, M., Curtius, J., Baltensperger, U., Worsnop, D. R., Vehkamäki, H., and Kirkby,
J.: Molecular understanding of sulfuric acid-amine particle nucleation in the atmosphere, Nature, 502, 359-363, 2013.

Barsanti, K. C., McMurry, P. H., and Smith, J. N.: The potential contribution of organic salts to new particle growth, Atmos. Chem. Phys., 9, 2949-2957, doi:10.5194/acp-9-2949-2009, 2009.

Berndt, T., Stratmann, F., Sipilä, M., Vanhanen, J., Petäjä, T., Mikkilä, J., Grüner, A., Spindler, G., Lee Mauldin III, R., Curtius, J., Kulmala, M., and Heintzenberg, J.: Laboratory study on new particle formation from the reaction $\mathrm{OH}+\mathrm{SO}_{2}$ : influence of experimental conditions, $\mathrm{H}_{2} \mathrm{O}$ vapour, $\mathrm{NH}_{3}$ and the amine tert-butylamine on the overall process, Atmos. Chem. Phys., 10, 7101-7116, doi:10.5194/acp-10-7101-2010, 2010.

Bianchi, F., Praplan, A. P., Sarnela, N., Dommen, J., Kürten, A., Ortega, I. K., Schobesberger, S., Junninen, H., Simon, M., Tröstl, J., Jokinen, T., Sipilä, M., Adamov, A., Amorim, A., Almeida, J., Breitenlechner, M., Duplissy, J., Ehrhart, S., Flagan, R. C., Franchin, A., Hakala, J., Hansel, A., Heinritzi, M., Kangasluoma, J., Keskinen, H., Kim, J., Kirkby, J., Laaksonen, A., Lawler, M. J., Lehtipalo, K., Leiminger, M., Makhmutov, V., Mathot, S., Onnela, A., Petäjä, T., Riccobono, F., Rissanen, M. P., Rondo, L., Tomé, A., Virtanen, A., Viisanen, Y., Williamson, C., Wimmer, D., Winkler, P. M., Ye, P., Curtius, J., Kulmala, M., Worsnop, D. R., Donahue, N. M., and Baltensperger, U.: Insight into acidbase nucleation experiments by comparison of the chemical composition of positive, negative, and neutral clusters, Environ. Sci. Technol., 48, 13675-13684, 2014.

Bzdek, B. R., Ridge, D. P., and Johnston, M. V.: Amine exchange into ammonium bisulfate and ammonium nitrate nuclei, Atmos. Chem. Phys., 10, 3495-3503, doi:10.5194/acp-10-3495-2010, 2010.

Chan, L. P. and Chan, C. K.: Role of the aerosol phase state in ammonia/amines exchange reactions, Environ. Sci. Technol., 47, 5755-5762, 2013.

Chang, R. Y.-W., Slowik, J. G., Shantz, N. C., Vlasenko, A., Liggio, J., Sjostedt, S. J., Leaitch, W. R., and Abbatt, J. P. D.: The hygroscopicity parameter $(\kappa)$ of ambient organic aerosol at a field site subject to biogenic and anthropogenic influences: relationship to degree of aerosol oxidation, Atmos. Chem. Phys., 10, 5047-5064, doi:10.5194/acp-10-5047-2010, 2010.

Chen, D. R., Pui, D. Y. H., Hummes, D., Fissan, H., Quant, F. R., and Sem, G. J.: Design and evaluation of a nanometer aerosol differential mobility analyzer (Nano-DMA), J. Aerosol Sci., 29, 497-509, 1998.

Choi, M. Y. and Chan, C. K.: The effects of organic species on the hygroscopic behaviors of inorganic aerosols, Environ. Sci. Technol., 36, 2422-2428, 2002.

Clegg, S. L., Pitzer, K. S., and Brimblecombe, P.: Thermodynamics of multicomponent, miscible, ionic solutions. 2. Mixtures including unsymmetrical electrolytes, J. Phys. Chem., 96, 9470-9479, 1992.

Clegg, S. L., Qiu, C., and Zhang, R.: The deliquescence behaviour, solubilities, and densities of aqueous solutions of five methyland ethyl-aminium sulphate salts, Atmos. Environ., 73, 145-158, 2013.

Donahue, N. M., Henry, K. M., Mentel, T. F., Kiendler-Scharr, A., Spindler, C., Bohn, B., Brauers, T., Dorn, H. P., Fuchs, H., Tillmann, R., Wahner, A., Saathoff, H., Naumann, K. H., Möhler, O., Leisner, T., Müller, L., Reinnig, M. C., Hoffmann, T., Salo, K., Hallquist, M., Frosch, M., Bilde, M., Tritscher, T., Barmet, P., 
Praplan, A. P., DeCarlo, P. F., Dommen, J., Prévôt, A. S. H., and Baltensperger, U.: Aging of biogenic secondary organic aerosol via gas-phase $\mathrm{OH}$ radical reactions, P. Natl. Acad. Sci. USA, 109, 13503-13508, 2012.

Duplissy, J., Gysel, M., Sjogren, S., Meyer, N., Good, N., Kammermann, L., Michaud, V., Weigel, R., Martins dos Santos, S., Gruening, C., Villani, P., Laj, P., Sellegri, K., Metzger, A., McFiggans, G. B., Wehrle, G., Richter, R., Dommen, J., Ristovski, Z., Baltensperger, U., and Weingartner, E.: Intercomparison study of six HTDMAs: results and recommendations, Atmos. Meas. Tech., 2, 363-378, doi:10.5194/amt-2-363-2009, 2009.

Duplissy, J., Enghoff, M. B., Aplin, K. L., Arnold, F., Aufmhoff, H., Avngaard, M., Baltensperger, U., Bondo, T., Bingham, R., Carslaw, K., Curtius, J., David, A., Fastrup, B., Gagné, S., Hahn, F., Harrison, R. G., Kellett, B., Kirkby, J., Kulmala, M., Laakso, L., Laaksonen, A., Lillestol, E., Lockwood, M., Mäkelä, J., Makhmutov, V., Marsh, N. D., Nieminen, T., Onnela, A., Pedersen, E., Pedersen, J. O. P., Polny, J., Reichl, U., Seinfeld, J. H., Sipilä, M., Stozhkov, Y., Stratmann, F., Svensmark, H., Svensmark, J., Veenhof, R., Verheggen, B., Viisanen, Y., Wagner, P. E., Wehrle, G., Weingartner, E., Wex, H., Wilhelmsson, M., and Winkler, P. M.: Results from the CERN pilot CLOUD experiment, Atmos. Chem. Phys., 10, 1635-1647, doi:10.5194/acp-101635-2010, 2010.

Duplissy, J., DeCarlo, P. F., Dommen, J., Alfarra, M. R., Metzger, A., Barmpadimos, I., Prevot, A. S. H., Weingartner, E., Tritscher, T., Gysel, M., Aiken, A. C., Jimenez, J. L., Canagaratna, M. R., Worsnop, D. R., Collins, D. R., Tomlinson, J., and Baltensperger, U.: Relating hygroscopicity and composition of organic aerosol particulate matter, Atmos. Chem. Phys., 11, 11551165, doi:10.5194/acp-11-1155-2011, 2011.

Duplissy, J., Merikanto, J., Franchin, A., Tsagkogeorgas, G., Kangasluoma, J., Wimmer, D., Vuollekoski, H., Schobesberger, S., Lehtipalo, K., Flagan, R.C., Brus, D., Donahue, N.M., Vehkämäki, H., Almeida, J., Amorim, A., Barmet, P., Bianchi, F., Breitenlechner, M., Dunne, E. M., Guida, R., Henschel, H., Junninen, H., Kirkby, J., Kürten, A., Kupc, A., Määttänen, A., Makhmutov, V., Mathot, S., Nieminen, T., Onnela, A., Praplan, A. P., Riccobono, F., Rondo, L., Steiner, G., Tome, A., Walther, H., Baltensperger, U., Carslaw, K. S., Dommen, J., Hansel, A., Petäjä, T., Sipilä, M., Stratmann, F., Vrtala, A., Wagner, P. E., Worsnop, D. R., Curtius, J., and Kulmala, M.: Effect of ions on sulfuric acid-water binary particle formation II: Experimental data and comparison with QC-normalized classical nucleation theory, J. Geophys. Res.-Atmos., 120, in press, doi:10.1002/2015JD023539, 2016.

Ehn, M., Thornton, J. A., Kleist, E., Sipilä, M., Junninen, H., Pullinen, I., Springer, M., Rubach, F., Tillmann, R., Lee, B., LopezHilfiker, F., Andres, S., Acir, I. H., Rissanen, M., Jokinen, T., Schobesberger, S., Kangasluoma, J., Kontkanen, J., Nieminen, T., Kurtén, T., Nielsen, L. B., Jørgensen, S., Kjaergaard, H. G., Canagaratna, M., Maso, M. D., Berndt, T., Petäjä, T., Wahner, A., Kerminen, V. M., Kulmala, M., Worsnop, D. R., Wildt, J., and Mentel, T. F.: A large source of low-volatility secondary organic aerosol, Nature, 506, 476-479, 2014.

Engelhart, G. J., Asa-Awuku, A., Nenes, A., and Pandis, S. N.: CCN activity and droplet growth kinetics of fresh and aged monoterpene secondary organic aerosol, Atmos. Chem. Phys., 8, 39373949, doi:10.5194/acp-8-3937-2008, 2008.
Erupe, M. E., Viggiano, A. A., and Lee, S.-H.: The effect of trimethylamine on atmospheric nucleation involving $\mathrm{H}_{2} \mathrm{SO}_{4}$, Atmos. Chem. Phys., 11, 4767-4775, doi:10.5194/acp-11-47672011, 2011.

Frosch, M., Bilde, M., DeCarlo, P. F., Jurányi, Z., Tritscher, T., Dommen, J., Donahue, N. M., Gysel, M., Weingartner, E., and Baltensperger, U.: Relating cloud condensation nuclei activity and oxidation level of $\alpha$-pinene secondary organic aerosols, J. Geophys. Res.-Atmos., 116, D22212, doi:10.1029/2011JD016401, 2011.

Ge, X., Wexler, A. S., and Clegg, S. L.: Atmospheric amines Part II. Thermodynamic properties and gas/particle partitioning, Atmos. Environ., 45, 561-577, 2011.

Griffin, R. J., Cocker Iii, D. R., Flagan, R. C., and Seinfeld, J. H.: Organic aerosol formation from the oxidation of biogenic hydrocarbons, J. Geophys. Res.-Atmos., 104, 3555-3567, 1999.

Hallquist, M., Wenger, J. C., Baltensperger, U., Rudich, Y., Simpson, D., Claeys, M., Dommen, J., Donahue, N. M., George, C., Goldstein, A. H., Hamilton, J. F., Herrmann, H., Hoffmann, T., Iinuma, Y., Jang, M., Jenkin, M. E., Jimenez, J. L., Kiendler-Scharr, A., Maenhaut, W., McFiggans, G., Mentel, Th. F., Monod, A., Prévôt, A. S. H., Seinfeld, J. H., Surratt, J. D., Szmigielski, R., and Wildt, J.: The formation, properties and impact of secondary organic aerosol: current and emerging issues, Atmos. Chem. Phys., 9, 5155-5236, doi:10.5194/acp-9-51552009, 2009.

Hämeri, K., Väkevä, M., Hansson, H. C., and Laaksonen, A.: Hygroscopic growth of ultrafine ammonium sulphate aerosol measured using an ultrafine tandem differential mobility analyzer, J. Geophys. Res.-Atmos., 105, 22231-22242, 2000.

Hao, L. Q., Romakkaniemi, S., Yli-Pirilä, P., Joutsensaari, J., Kortelainen, A., Kroll, J. H., Miettinen, P., Vaattovaara, P., Tiitta, P., Jaatinen, A., Kajos, M. K., Holopainen, J. K., Heijari, J., Rinne, J., Kulmala, M., Worsnop, D. R., Smith, J. N., and Laaksonen, A.: Mass yields of secondary organic aerosols from the oxidation of $\alpha$-pinene and real plant emissions, Atmos. Chem. Phys., 11, 1367-1378, doi:10.5194/acp-11-1367-2011, 2011.

Hennigan, C. J., Miracolo, M. A., Engelhart, G. J., May, A. A., Presto, A. A., Lee, T., Sullivan, A. P., McMeeking, G. R., Coe, H., Wold, C. E., Hao, W.-M., Gilman, J. B., Kuster, W. C., de Gouw, J., Schichtel, B. A., Collett Jr., J. L., Kreidenweis, S. M., and Robinson, A. L.: Chemical and physical transformations of organic aerosol from the photo-oxidation of open biomass burning emissions in an environmental chamber, Atmos. Chem. Phys., 11, 7669-7686, doi:10.5194/acp-11-7669-2011, 2011.

Henry, K. M. and Donahue, N. M.: Photochemical aging of $\alpha$ pinene secondary organic aerosol: Effects of $\mathrm{OH}$ radical sources and photolysis, J. Phys. Chem. A, 116, 5932-5940, 2012.

Henry, K. M., Lohaus, T., and Donahue, N. M.: Organic aerosol yields from $\alpha$-pinene oxidation: Bridging the gap between firstgeneration yields and aging chemistry, Environ. Sci. Technol., 46, 12347-12354, 2012.

Hyvärinen, A. P., Lihavainen, H., Hautio, K., Raatikainen, T., Viisanen, Y., and Laaksonen A.: Surface Tensions and Densities of Sulfuric Acid + Dimethylamine + Water Solutions, J. Chem. Eng. Data, 49, 917-922, 2004.

IPCC: Climate change 2013: The physical science basis, Intergovernmental panel on Climate Change, Cambridge University Press, New York, USA, 571-740, 2013. 
Jimenez, J. L., Canagaratna, M. R., Donahue, N. M., Prévôt, A. S. H., Zhang, Q., Kroll, J. H., DeCarlo, P. F., Allan, J. D., Coe, H., Ng, N. L., Aiken, A. C., Docherty, K. S., Ulbrich, I. M., Grieshop, A. P., Robinson, A. L., Duplissy, J., Smith, J. D., Wilson, K. R., Lanz, V. A., Hueglin, C., Sun, Y. L., Tian, J., Laaksonen, A., Raatikainen, T., Rautiainen, J., Vaattovaara, P., Ehn, M., Kulmala, M., Tomlinson, J. M., Collins, D. R., Cubison, M. J., Dunlea, E. J., Huffman, J. A., Onasch, T. B., Alfarra, M. R., Williams, P. I., Bower, K., Kondo, Y., Schneider, J., Drewnick, F., Borrmann, S., Weimer, S., Demerjian, K., Salcedo, D., Cottrell, L., Griffin, R., Takami, A., Miyoshi, T., Hatakeyama, S., Shimono, A., Sun, J. Y., Zhang, Y. M., Dzepina, K., Kimmel, J. R., Sueper, D., Jayne, J. T., Herndon, S. C., Trimborn, A. M., Williams, L. R., Wood, E. C., Middlebrook, A. M., Kolb, C. E., Baltensperger, U., and Worsnop, D. R.: Evolution of organic aerosols in the atmosphere, Science, 326, 1525-1529, 2009.

Jurányi, Z., Gysel, M., Duplissy, J., Weingartner, E., Tritscher, T., Dommen, J., Henning, S., Ziese, M., Kiselev, A., Stratmann, F., George, I., and Baltensperger, U.: Influence of gas-to-particle partitioning on the hygroscopic and droplet activation behaviour of $\alpha$-pinene secondary organic aerosol, Phys. Chem. Chem. Phys., 11, 8091-8097, 2009.

Keskinen, H., Romakkaniemi, S., Jaatinen, A., Miettinen, P., Saukko, E., Jorma, J., Makela, J. M., Virtanen, A., Smith, J. N., and Laaksonen, A.: On-line characterization of morphology and water adsorption on fumed silica nanoparticles, Aerosol Sci. Technol., 45, 1441-1447, 2011.

Keskinen, H., Virtanen, A., Joutsensaari, J., Tsagkogeorgas, G., Duplissy, J., Schobesberger, S., Gysel, M., Riccobono, F., Slowik, J. G., Bianchi, F., Yli-Juuti, T., Lehtipalo, K., Rondo, L., Breitenlechner, M., Kupc, A., Almeida, J., Amorim, A., Dunne, E. M., Downard, A. J., Ehrhart, S., Franchin, A., Kajos, M.K., Kirkby, J., Kürten, A., Nieminen, T., Makhmutov, V., Mathot, S., Miettinen, P., Onnela, A., Petäjä, T., Praplan, A., Santos, F. D., Schallhart, S., Sipilä, M., Stozhkov, Y., Tomé, A., Vaattovaara, P., Wimmer, D., Prevot, A., Dommen, J., Donahue, N. M., Flagan, R.C., Weingartner, E., Viisanen, Y., Riipinen, I., Hansel, A., Curtius, J., Kulmala, M., Worsnop, D. R., Baltensperger, U., Wex, H., Stratmann, F., and Laaksonen, A.: Evolution of particle composition in CLOUD nucleation experiments, Atmos. Chem. Phys., 13, 5587-5600, doi:10.5194/acp-13-5587-2013, 2013.

Kim, J.-S., Kim, Y. J., and Park, K.: Measurements of hygroscopicity and volatility of atmospheric ultrafine particles in the rural Pearl River Delta area of China, Atmos. Environ., 45, 46614670, 2011.

Kirkby, J., Curtius, J., Almeida, J., Dunne, E., Duplissy, J., Ehrhart, S., Franchin, A., Gagné, S., Ickes, L., Kürten, A., Kupc, A., Metzger, A., Riccobono, F., Rondo, L., Schobesberger, S., Tsagkogeorgas, G., Wimmer, D., Amorim, A., Bianchi, F., Breitenlechner, M., David, A., Dommen, J., Downard, A., Ehn, M., Flagan, R. C., Haider, S., Hansel, A., Hauser, D., Jud, W., Junninen, H., Kreissl, F., Kvashin, A., Laaksonen, A., Lehtipalo, K., Lima, J., Lovejoy, E. R., Makhmutov, V., Mathot, S., Mikkilä, J., Minginette, P., Mogo, S., Nieminen, T., Onnela, A., Pereira, P., Petäjä, T., Schnitzhofer, R., Seinfeld, J. H., Sipilä, M., Stozhkov, Y., Stratmann, F., Tomé, A., Vanhanen, J., Viisanen, Y., Vrtala, A., Wagner, P. E., Walther, H., Weingartner, E., Wex, H., Winkler, P. M., Carslaw, K. S., Worsnop, D. R., Baltensperger, U., and Kulmala,
M.: Role of sulfuric acid, ammonia and galactic cosmic rays in atmospheric aerosol nucleation, Nature, 476, 429-435, 2011.

Kroll, J. H., Ng, N. L., Murphy, S. M., Flagan, R. C., and Seinfeld, J. H.: Secondary organic aerosol formation from isoprene photooxidation under high- $\mathrm{NO}_{x}$ conditions, Geophys. Res. Lett., 32, $1-4,2005$.

Kulmala, M., Vehkamäki, H., Petäjä, T., Dal Maso, M., Lauri, A., Kerminen, V. M., Birmili, W., and McMurry, P. H.: Formation and growth rates of ultrafine atmospheric particles: A review of observations, J. Aerosol. Sci., 35, 143-176, 2004.

Kupc, A., Amorim, A., Curtius, J., Danielczok, A., Duplissy, J., Ehrhart, S., Walther, H., Ickes, L., Kirkby, J., Kürten, A., Lima, J. M., Mathot, S., Minginette, P., Onnela, A., Rondo, L., and Wagner, P. E.: A fibre-optic UV system for $\mathrm{H}_{2} \mathrm{SO}_{4}$ production in aerosol chambers causing minimal thermal effects, J. Aerosol. Sci., 42, 532-543, 2011.

Kürten, A., Rondo, L., Ehrhart, S., and Curtius, J.: Performance of a corona ion source for measurement of sulfuric acid by chemical ionization mass spectrometry, Atmos. Meas. Tech., 4, 437-443, doi:10.5194/amt-4-437-2011, 2011.

Kürten, A., Jokinen, T., Simon, M., Sipilä, M., Sarnela, N., Junninen, H., Adamov, A., Almeida, J., Amorim, A., Bianchi, F., Breitenlechner, M., Dommen, J., Donahue, N. M., Duplissy, J., Ehrhart, S., Flagan, R. C., Franchin, A., Hakala, J., Hansel, A., Heinritzi, M., Hutterli, M., Kangasluoma, J., Kirkby, J., Laaksonen, A., Lehtipalo, K., Leiminger, M., Makhmutov, V., Mathot, S., Onnela, A., Petäjä, T., Praplan, A. P., Riccobono, F., Rissanen, M. P., Rondo, L., Schobesberger, S., Seinfeld, J. H., Steiner, G., Tomé, A., Tröstl, J., Winkler, P. M., Williamson, C., Wimmer, D., Ye, P., Baltensperger, U., Carslaw, K. S., Kulmala, M., Worsnop, D. R., and Curtius, J.: Neutral molecular cluster formation of sulfuric acid-dimethylamine observed in real time under atmospheric conditions, P. Natl. Acad. Sci. USA, 111, 1501915024, 2014.

Kurtén, T., Loukonen, V., Vehkamäki, H., and Kulmala, M.: Amines are likely to enhance neutral and ion-induced sulfuric acid-water nucleation in the atmosphere more effectively than ammonia, Atmos. Chem. Phys., 8, 4095-4103, doi:10.5194/acp-8-4095-2008, 2008.

Lambe, A. T., Onasch, T. B., Massoli, P., Croasdale, D. R., Wright, J. P., Ahern, A. T., Williams, L. R., Worsnop, D. R., Brune, W. H., and Davidovits, P.: Laboratory studies of the chemical composition and cloud condensation nuclei (CCN) activity of secondary organic aerosol (SOA) and oxidized primary organic aerosol (OPOA), Atmos. Chem. Phys., 11, 8913-8928, doi:10.5194/acp11-8913-2011, 2011.

Lawler, M., Smith, J. N., Winkler, P. M., Tröstl, J., Praplan, A., Schobesberger, S., Kim, J., Virtanen, A., Ahlm, L., Riipinen, I., and CLOUD Consortium: Acidic freshly nucleated sulfate particle: Relative roles of dimethylamine and ammonia, in preparation, 2016.

Loukonen, V., Kurtén, T., Ortega, I. K., Vehkamäki, H., Pádua, A. A. H., Sellegri, K., and Kulmala, M.: Enhancing effect of dimethylamine in sulfuric acid nucleation in the presence of water - a computational study, Atmos. Chem. Phys., 10, 49614974, doi:10.5194/acp-10-4961-2010, 2010.

Massoli, P., Lambe, A. T., Ahern, A. T., Williams, L. R., Ehn, M., Mikkilä, J., Canagaratna, M. R., Brune, W. H., Onasch, T. B., Jayne, J. T., Petäjä, T., Kulmala, M., Laaksonen, A., Kolb, C. 
E., Davidovits, P., and Worsnop, D. R.: Relationship between aerosol oxidation level and hygroscopic properties of laboratory generated secondary organic aerosol (SOA) particles, Geophys. Res. Lett., 37, L24801, doi:10.1029/2010GL045258, 2010.

McMurry, P. H. and Stolzenburg, M. R.: On the sensitivity of particle size to relative humidity for Los Angeles aerosols, Atmos. Environ., 23, 497-507, 1989.

Metzger, A., Verheggen, B., Dommen, J., Duplissy, J., Prévôt, A. S. H., Weingartner, E., Riipinen, I., Kulmala, M., Spracklen, D. V., Carslaw, K. S., and Baltensperger, U.: Evidence for the role of organics in aerosol particle formation under atmospheric conditions, P. Natl. Acad. Sci. USA, 107, 6646-6651, 2010.

Meyer, N. K., Duplissy, J., Gysel, M., Metzger, A., Dommen, J., Weingartner, E., Alfarra, M. R., Prevot, A. S. H., Fletcher, C., Good, N., McFiggans, G., Jonsson, A. M., Hallquist, M., Baltensperger, U., and Ristovski, Z. D.: Analysis of the hygroscopic and volatile properties of ammonium sulphate seeded and unseeded SOA particles, Atmos. Chem. Phys., 9, 721-732, doi:10.5194/acp-9-721-2009, 2009.

Ouyang, H., He, S., Larriba-Andaluz, C., and Hogan, C. J.: IMSMS and IMS-IMS Investigation of the Structure and Stability of Dimethylamine-Sulfuric Acid Nanoclusters, J. Phys. Chem. A, 119, 2026-2036, doi:10.1021/jp512645g, 2015.

Paasonen, P., Olenius, T., Kupiainen, O., Kurtén, T., Petäjä, T., Birmili, W., Hamed, A., Hu, M., Huey, L. G., Plass-Duelmer, C., Smith, J. N., Wiedensohler, A., Loukonen, V., McGrath, M. J., Ortega, I. K., Laaksonen, A., Vehkamäki, H., Kerminen, V.-M., and Kulmala, M.: On the formation of sulphuric acid - amine clusters in varying atmospheric conditions and its influence on atmospheric new particle formation, Atmos. Chem. Phys., 12, 9113-9133, doi:10.5194/acp-12-9113-2012, 2012.

Pajunoja, A., Lambe, A. T., Hakala, J., Rastak, N., Cummings, M. J., Brogan, J. F., Hao, L., Paramonov, M., Hong, J., Prisle, N. L., Malila, J., Romakkaniemi, S., Lehtinen, K. E. J., Laaksonen, A., Kulmala, M., Massoli, P., Onasch, T. B., Donahue, N. M., Riipinen, I., Davidovits, P., Worsnop, D. R., Petäjä, T., and Virtanen, A.: Adsorptive uptake of water by semisolid secondary organic aerosols, Geophys. Res. Lett., 42, 3063-3068, doi:10.1002/2015g1063142, 2015.

Petters, M. D. and Kreidenweis, S. M.: A single parameter representation of hygroscopic growth and cloud condensation nucleus activity, Atmos. Chem. Phys., 7, 1961-1971, doi:10.5194/acp-71961-2007, 2007.

Pierce, J. R., Riipinen, I., Kulmala, M., Ehn, M., Petäjä, T., Junninen, H., Worsnop, D. R., and Donahue, N. M.: Quantification of the volatility of secondary organic compounds in ultrafine particles during nucleation events, Atmos. Chem. Phys., 11, 90199036, doi:10.5194/acp-11-9019-2011, 2011.

Praplan, A. P., Schobesberger, S., Bianchi, F., Rissanen, M. P., Ehn, M., Jokinen, T., Junninen, H., Adamov, A., Amorim, A., Dommen, J., Duplissy, J., Hakala, J., Hansel, A., Heinritzi, M., Kangasluoma, J., Kirkby, J., Krapf, M., Kürten, A., Lehtipalo, K., Riccobono, F., Rondo, L., Sarnela, N., Simon, M., Tomé, A., Tröstl, J., Winkler, P. M., Williamson, C., Ye, P., Curtius, J., Baltensperger, U., Donahue, N. M., Kulmala, M., and Worsnop, D. R.: Elemental composition and clustering behaviour of $\alpha$ pinene oxidation products for different oxidation conditions, Atmos. Chem. Phys., 15, 4145-4159, doi:10.5194/acp-15-4145$2015,2015$.
Pratt, K. A., Hatch, L. E., and Prather, K. A.: Seasonal volatility dependence of ambient particle phase amines, Environ. Sci. Technol., 43, 5276-5281, 2009.

Qiu, C. and Zhang, R.: Physiochemical properties of alkylaminium sulfates: Hygroscopicity, thermostability, and density, Environ. Sci. Technol., 46, 4474-4480, 2012.

Reischl, G. P.: Measurement of ambient aerosols by the differential mobility analyzer method: Concepts and realization criteria for the size range between 2 and $500 \mathrm{~nm}$, Aerosol Sci. Technol., 14, 5-24, 1991.

Riccobono, F., Schobesberger, S., Scott, C. E., Dommen, J., Ortega, I. K., Rondo, L., Almeida, J., Amorim, A., Bianchi, F., Breitenlechner, M., David, A., Downard, A., Dunne, E. M., Duplissy, J., Ehrhart, S., Flagan, R. C., Franchin, A., Hansel, A., Junninen, H., Kajos, M., Keskinen, H., Kupc, A., Kürten, A., Kvashin, A. N., Laaksonen, A., Lehtipalo, K., Makhmutov, V., Mathot, S., Nieminen, T., Onnela, A., Petäjä, T., Praplan, A. P., Santos, F. D., Schallhart, S., Seinfeld, J. H., Sipilä, M., Spracklen, D. V., Stozhkov, Y., Stratmann, F., Tomé, A., Tsagkogeorgas, G., Vaattovaara, P., Viisanen, Y., Vrtala, A., Wagner, P. E., Weingartner, E., Wex, H., Wimmer, D., Carslaw, K. S., Curtius, J., Donahue, N. M., Kirkby, J., Kulmala, M., Worsnop, D. R., and Baltensperger, U.: Oxidation products of biogenic emissions contribute to nucleation of atmospheric particles, Science, 344, 717 721, 2014.

Riipinen, I., Manninen, H. E., Yli-Juuti, T., Boy, M., Sipilä, M., Ehn, M., Junninen, H., Petäjä, T., and Kulmala, M.: Applying the Condensation Particle Counter Battery (CPCB) to study the water-affinity of freshly-formed 2-9 nm particles in boreal forest, Atmos. Chem. Phys., 9, 3317-3330, doi:10.5194/acp-9-33172009, 2009.

Ristovski, Z. D., Suni, T., Kulmala, M., Boy, M., Meyer, N. K., Duplissy, J., Turnipseed, A., Morawska, L., and Baltensperger, U.: The role of sulphates and organic vapours in growth of newly formed particles in a eucalypt forest, Atmos. Chem. Phys., 10, 2919-2926, doi:10.5194/acp-10-2919-2010, 2010.

Roberts, G. C., Day, D. A., Russell, L. M., Dunlea, E. J., Jimenez, J. L., Tomlinson, J. M., Collins, D. R., Shinozuka, Y., and Clarke, A. D.: Characterization of particle cloud droplet activity and composition in the free troposphere and the boundary layer during INTEX-B, Atmos. Chem. Phys., 10, 6627-6644, doi:10.5194/acp-10-6627-2010, 2010.

Sakurai, H., Fink, M. A., McMurry, P. H., Mauldin, L., Moore, K. F., Smith, J. N., and Eisele, F. L.: Hygroscopicity and volatility of 4-10 nm particles during summertime atmospheric nucleation events in urban Atlanta, J. Geophys. Res.-Atmos., 110, 1$10,2005$.

Schnitzhofer, R., Metzger, A., Breitenlechner, M., Jud, W., Heinritzi, M., De Menezes, L.-P., Duplissy, J., Guida, R., Haider, S., Kirkby, J., Mathot, S., Minginette, P., Onnela, A., Walther, H., Wasem, A., Hansel, A., and the CLOUD Team: Characterisation of organic contaminants in the CLOUD chamber at CERN, Atmos. Meas. Tech., 7, 2159-2168, doi:10.5194/amt-7-2159-2014, 2014.

Shantz, N. C., Leaitch, W. R., Phinney, L., Mozurkewich, M., and Toom-Sauntry, D.: The effect of organic compounds on the growth rate of cloud droplets in marine and forest settings, Atmos. Chem. Phys., 8, 5869-5887, doi:10.5194/acp-8-5869-2008, 2008. 
Sjogren, S., Gysel, M., Weingartner, E., Alfarra, M. R., Duplissy, J., Cozic, J., Crosier, J., Coe, H., and Baltensperger, U.: Hygroscopicity of the submicrometer aerosol at the high-alpine site Jungfraujoch, $3580 \mathrm{~m}$ a.s.l., Switzerland, Atmos. Chem. Phys., 8, 5715-5729, doi:10.5194/acp-8-5715-2008, 2008.

Smith, J. N., Moore, K. F., McMurry, P. H., and Eisele, F. L.: Atmospheric Measurements of Sub-20 nm Diameter Particle Chemical Composition by Thermal Desorption Chemical Ionization Mass Spectrometry, Aerosol Sci. Technol., 38, 100-110, 2004.

Smith, J. N., Barsantia, K. C., Friedlia, H. R., Ehnd, M., Kulmala, M., Collins, D. R., Scheckman, J. H., Williams, B. J., and McMurry, P. H.: Observations of aminium salts in atmospheric nanoparticles and possible climatic implications, P. Natl. Acad. Sci. USA, 107, 6634-6639, 2010.

Sullivan, R. C., Petters, M. D., DeMott, P. J., Kreidenweis, S. M., Wex, H., Niedermeier, D., Hartmann, S., Clauss, T., Stratmann, F., Reitz, P., Schneider, J., and Sierau, B.: Irreversible loss of ice nucleation active sites in mineral dust particles caused by sulphuric acid condensation, Atmos. Chem. Phys., 10, 1147111487, doi:10.5194/acp-10-11471-2010, 2010.

Topping, D. O., McFiggans, G. B., and Coe, H.: A curved multicomponent aerosol hygroscopicity model framework: Part 1 - Inorganic compounds, Atmos. Chem. Phys., 5, 1205-1222, doi:10.5194/acp-5-1205-2005, 2005.

Varutbangkul, V., Brechtel, F. J., Bahreini, R., Ng, N. L., Keywood, M. D., Kroll, J. H., Flagan, R. C., Seinfeld, J. H., Lee, A., and Goldstein, A. H.: Hygroscopicity of secondary organic aerosols formed by oxidation of cycloalkenes, monoterpenes, sesquiterpenes, and related compounds, Atmos. Chem. Phys., 6, 23672388, doi:10.5194/acp-6-2367-2006, 2006.
Virkkula, A., Van Dingenen, R., Raes, F., and Hjorth, J.: Hygroscopic properties of aerosol formed by oxidation of limonene, $\alpha$-pinene, and $\beta$-pinene, J. Geophys. Res.-Atmos., 104, 35693579, 1999.

Voigtländer, J., Duplissy, J., Rondo, L., Kürten, A., and Stratmann, F.: Numerical simulations of mixing conditions and aerosol dynamics in the CERN CLOUD chamber, Atmos. Chem. Phys., 12, 2205-2214, doi:10.5194/acp-12-2205-2012, 2012.

Weber, R. J., Marti, J. J., McMurry, P. H., Eisele, F. L., Tanner, D. J., and Jefferson, A.: Measurements of new particle formation and ultrafine particle growth rates at a clean continental site, J. Geophys. Res.-Atmos., 102, 4375-4385, 1997.

Wexler, A. S. and Clegg, S. L.: Atmospheric aerosol models for systems including the ions $\mathrm{H}^{+}, \mathrm{NH}_{4}^{+}, \mathrm{Na}^{+}, \mathrm{SO}_{4}^{2-}, \mathrm{NO}_{3}^{-}$, $\mathrm{Cl}^{-}, \mathrm{Br}^{-}$, and $\mathrm{H}_{2} \mathrm{O}$, J. Geophys. Res.-Atmos., 107, 4207, doi:10.1029/2001JD000451, 2002.

Yasmeen, F., Vermeylen, R., Maurin, N., Perraudin, E., Doussin, J. F., and Claeys, M.: Characterisation of tracers for aging of $\alpha$-pinene secondary organic aerosol using liquid chromatography/negative ion electrospray ionisation mass spectrometry, Environ. Chem., 9, 236-246, 2012.

Zhao, J., Smith, J. N., Eisele, F. L., Chen, M., Kuang, C., and McMurry, P. H.: Observation of neutral sulfuric acid-amine containing clusters in laboratory and ambient measurements, Atmos. Chem. Phys., 11, 10823-10836, doi:10.5194/acp-1110823-2011, 2011. 